\title{
Rethinking general education in the English upper secondary system
}

\author{
Ann Hodgson* and Ken Spours \\ Institute of Education, University of London, London, UK
}

\begin{abstract}
The Secretary of State for Education's recent announcement of an English Baccalaureate at 16+ has opened up a debate about the nature of general education in the English upper secondary system. Drawing on evidence from national and local studies, we argue that it is important to see general education in England, not only in terms of the curriculum, but also as the product of a range of inter-related factors, which together form a 'model'. Using this analytical framework, we describe and analyse the two models of general education associated with the New Labour and Coalition administrations respectively. We conclude by suggesting a set of challenges and principles to inform the development of a third, curriculum-led model.
\end{abstract}

Keywords: general education; upper secondary education; GCSEs and A levels; knowledge; comprehensiveness; vocational education; the English Baccalaureate

\section{General education in the English system}

The announcement by Secretary of State for Education, Michael Gove, of an English Baccalaureate as a prime measure of secondary education performance at the age of 16 (Gove 2010) marked a new emphasis on the role of general education in the English upper secondary system, which is undertaken by young people between the ages of 14 and 19. As the subsequent schools White Paper - The importance of teaching (DfE 20I0a) - outlined, the English Baccalaureate comprises the acquisition of five 'good' General Certificate of Secondary Education (GCSE) grades in English, mathematics, science, a language and either history or geography. The Conservative/Liberal Democrat Coalition Government demand for a prescribed group of examined subjects in upper secondary education might not be controversial in other countries, but in England it potentially marks a turning point because a largely open choice of examination subjects at 16+ has been the tradition since the early 1950s. It is thus important to see the English Baccalaureate within the context of the history of 'general education', often referred to as 'the academic route'.

While the use of the term 'general education' to refer to an upper secondary curriculum based on academic disciplines is a relatively recent phenomenon in England, it is found in the title of the two main qualifications that have largely been used to define it - the GCSE and the General Certificate of Education (GCE A level). 'Liberal education' has often been used, but its definition is contested. Some have used this term when wishing to distinguish academic study from 'vocational preparation' (e.g., Pring 1995), although 'liberal education' has traditionally been associated with the much narrower classical curriculum that was taught in the English public schools for landed aristocracy and clergy, with its sense of cultural dis-

\footnotetext{
*Corresponding author. Email: A.Hodgson@ioe.ac.uk
} 
tance from the world of production and its ties to Oxford and Cambridge universities (Green 1990). As Green argues, the historically dominant liberal education approach to the curriculum that persisted until the early twentieth century and continued even then to deeply influence education in the majority of public or independent schools, might be seen as a product of the English 'liberal state'.

'General education', on the other hand, while including aspects of this traditional liberal education, also contains the more 'modern' subjects such as the sciences and technology that were required both for industrialisation and for an expanded education system (Gordon 2002). Throughout the twentieth century, as education spread beyond the upper and middle classes, the link between type of school and curriculum persisted and was further reinforced through the 1944 Education Act with its concept of a tripartite schooling system - grammar, secondary modern and grammar/technical (McCulloch 2002). It was grammar schools that primarily carried the banner of the general education tradition and this was codified in 1951 through the introduction of school leaving examinations in the individual subjects of the general education curriculum - General Certificate Ordinary Levels at 15/16 and Advanced Levels at 17//8. While a discussion of the school curriculum continued throughout the 1950s and 60s (e.g., Crowther 1959; Newsom 1963), it was not until the 1970s, with the advent of comprehensive schools, the raising of the school leaving age and the economic crisis that led to the Great Education Debate in 1976, that a more vigorous public debate began about the nature of upper secondary education and the role of both general and vocational education within it (e.g., DES 1976; Hopkins 1978; Dale 1985; Gleeson 1987).

The 1980s saw the rapid formation of a national upper secondary education and training system based on what might be termed a more 'bureaucratic' and centralised approach, focused predominantly on qualifications reform. It included the last stage of the National Curriculum, Key Stage 4, which was centred around general education subjects and the common GCSE examination at 16+; and the introduction of national vocational qualifications (NVQs) for young people and adults undertaking education and training in or related to the workplace. With the advent of General National Vocational Qualifications (GNVQs) in 1992, the stage was set for the triple-track national qualifications system that emerged in the early 1990s and largely determined the curriculum experience for all 14- to 19-year-olds (Hodgson and Spours 1997). However, within this bureaucratic era, approaches to general education reform show an underlying pattern of more 'progressive' or more 'regressive' phases. The former stressed the importance of creating greater access to general education and shifting its boundaries by creating linkages and equivalences between academic and vocational learning in the pursuit of 'parity of esteem', together with a wider range of assessment techniques for certificating learning and a more comprehensive approach to institutional organisation. The regressive phases emphasised the preservation of distinctions between academic and vocational tracks through assessment, modes of learning and specialised and differentiated institutions. In both phases, the bureaucratic approach to general education relied on the use of key policy steering mechanisms associated with new public management (Newman 2000) - targets, performance tables, inspection, funding - to modify institutional behaviour (see Hodgson and Spours 2008 for a more detailed discussion of these phases).

\section{Factors shaping general education in the upper secondary phase}

Given the bureaucratic development of curriculum and qualifications over the last two decades, it is important to see curriculum reform and the debates about general education in relation to the institutional and accountability arrangements that surround it. Tim Oates, in 
his paper, Could do better (Oates 2010), uses the term 'control factors' to describe a similar phenomenon in relation to the National Curriculum in England. The powerful influence of national policy levers on institutional decision-making and translation of national policy in England has been clearly demonstrated in the work of Coffield and colleagues (2008). In this article we both draw on that work and reflect on two current projects in different parts of England, the Kingswood Area Progression Project and the North East Lincolnshire Transition and Progression at 14+ Project, which provide more recent case study evidence of the effects of national policy on the shape of the upper secondary curriculum (for more detail on these projects see http:/www.ioe.ac.uk/research/3273I.html and http:/www.ioe.ac.uk/ research/49007.html). These two case studies have been invaluable in illustrating the ways in which curriculum planning is undertaken, what national and local factors are taken into consideration in its design and how learner programmes are constructed.

In this paper we recognise, therefore, that the upper secondary education curriculum in England, and the model of general education within it, is shaped not only by national qualifications and curriculum policy, but also by a complex and inter-related configuration of factors at the national, local and institutional levels. These include national policies related to institutional type or specialism, accountability measures such as nationally devised performance tables, the inspection regime and funding, together with the degree of provider competition or collaboration in the local 'ecology' (Hodgson and Spours 2009) and the role of each individual institution within this ecology. This leads us to suggest that in discussing general education we need an analytical framework that goes beyond curriculum debates around the strengths and weaknesses of liberal education (e.g., Pring 1995; Conway 2010).

\section{The New Labour general education model - a bureaucratic approach to opening access and broadening study}

During almost a decade of continuous qualifications reform (1999-2008), the Labour Government increased accessibility to general education in the upper secondary phase by a combination of measures - a two-stage A level, the introduction of modular assessment as a main system feature, the encouragement to mix general and applied study and the design of the 14-19 Diplomas, which were intended to lead to higher education as well as to the workplace. For example, Curriculum 2000, which had a major focus on 'broadening the advanced level curriculum' (Blackstone 1998) was secured not by an overarching curriculum framework, but through inspection, funding, performance measures and generous credit for AS level attainment to support schools and colleges in encouraging learners to take these larger advanced level programmes.

Following criticisms of Curriculum 2000 (DfES 2003), there was an opportunity for New Labour to take a different approach. Over a period of 18 months between 2003 and 2004, the Tomlinson Working Group on 14-19 Reform (2004) developed a blueprint for a unified diploma system that would eventually subsume all types of learning and qualifications within a single framework, together with a much greater accent on the role of professionals in the assessment process. If these reforms had been adopted, they would have represented a marked departure from the English general education tradition insofar as they could have led to a more curriculum-focused and less bureaucratic and divided approach to general education. Perhaps it is for this reason the Tomlinson recommendations were not implemented. Instead, New Labour published its White Paper, 14-19 education and skills (DfES 2005a), which described GCSEs and A levels as the 'cornerstones' of the English system and proposed the introduction of a new Specialist Diploma in 14 broad vocational areas 
alongside these established qualifications. The preservation of GCSEs and A levels and the division between general and vocational education was somewhat 'softened' or blurred by a series of measures taken between 2005 and 2010. The mixing of study that gradually began to take place in Key Stage 4 as a result of the Increased Flexibility Programme (Golden, O'Donnell, and Rudd 2005), together with the opportunity to study not only applied GCSEs but also BTEC qualifications and Diplomas, was codified through new performance measures that recognised equivalences between general and applied/vocational qualifications and offered generous credit to the latter. Schools, and particularly those under pressure from Ofsted inspection to improve their performance at the end of Key Stage 4, not only took up these qualifications in great number but also, in some cases, as our case-study research show made them a mandatory part of learners' programmes (KAPP Discussion Paper 10 20I0a; NELP Discussion Paper I 20II).

This model of boundary blurring between general and applied/vocational qualifications was taken to another stage in the design of the 14-19 Diplomas, which encouraged the inclusion of GCSEs and A levels as part of the overall programme of study. The Diplomas were the focus of unprecedented financial investment and promotion by Ministers, one of whom hoped that they would become the 'qualification of choice' for learners in the upper secondary phase (BBC News 2007). This aspiration was supported by a statutory 14-19 entitlement, which expected local authorities to offer all 14 lines of Diplomas at all three levels alongside GCSEs and A levels in their locality and schools and colleges to collaborate to make this offer a reality (DfES 2005b). Had these aims been realised, the Diplomas might have redefined general education for 14- to 19-year-olds. However, they quickly foundered in a track-based qualifications system dominated by GCSEs and A levels and in the event only a very small proportion of 16- to 19-year-olds are currently taking these programmes, particularly at level 3.

The New Labour model of general education had some positive effects in terms of improved A level and GCSE (and equivalents) performance, together with rises in full-time post-I6 participation (DfE and BIS 20I0a, b, 20II). Evidence from our local studies demonstrates that 'middle attainers' (classified according to Key Stage 2 SATs scores) were particular beneficiaries because a greater proportion achieved the five GCSE $A^{*}-C$ grades or equivalent threshold required to enter level 3 study post-I6 (KAPP Discussion Paper II 20lOb). This local evidence also suggests that these new Key Stage 4 graduates were more likely to opt for A levels rather than alternative applied or vocational programmes. The strategy of mixing of qualifications and assigning them equivalences thus appeared to increase aspirations to study general education beyond the age of 16 in a landscape dominated by $A$ levels.

This approach to general education, however, harboured some serious weaknesses. Interviews with post-16 admissions tutors in the Kingswood Area Progression Project raised questions as to whether the new middle attaining 16-year-olds were acquiring the skills and knowledge to effectively make the difficult transition between level 2 and level 3 study, and from mixed Key Stage 4 programmes to A levels in particular (KAPP Discussion Paper 12 2010c). In some respects, it was reproducing some of the deficiencies of the Curriculum 2000 approach to A level study, which encouraged mechanical learning and the banking of credit (Fisher 2007), rather than 'deep learning' (de Waal 2009).

At the level of the school curriculum, the rush by some institutions to embrace applied qualifications in Key Stage 4 to maximise their points scores in performance tables, paralleled a swift decline of more traditional general education subjects such as modern foreign languages, history, geography and the taking of all three sciences, to the extent that these subjects were increasingly becoming the preserve of selective and independent schools 
(Richardson 2009). Moreover, many learners, particularly in comprehensive schools in poorer areas, such as those in one of our case studies, were unable to access these subjects because of the way that timetables had been constructed. They were thus precluded from certain forms of post-16 study and career options that depended on the acquisition of more traditional general education subjects (NELPP Discussion Paper I 20I0).

New Labour's approach to general education in the upper secondary phase was essentially pragmatic and bureaucratic. While increasing access and broadening study were important, the central aim of its 14-19 strategy was to improve participation and attainment. The elevation of performativity, however, meant that there was no strong narrative about the purposes of 14-19 education and training and the role of general education within it. Moreover, the emphasis on implementing the 14-19 reforms from 2005 onwards, and the reliance on the Diplomas to deliver the reform agenda, meant that there was also no room for serious evaluation, debate or dissent. Bigger questions about the purposes of the upper secondary curriculum, including the role of knowledge, were increasingly held away from centre stage. The Nuffield Review of 14-19 education and training in England and Wales (Pring et al. 2009) debated the former, but the issue of knowledge remained relatively neglected (Young and Muller 2010). While New Labour's bureaucratic strategy delivered some significant gains in performance, it lacked an underlying philosophical coherence and was vulnerable in terms of 'standards'. These were to be exploited by right-wing think tanks, such as Reform, Policy Exchange and Civitas, in the period before the General Election through a number of searing critiques (Bassett et al. 2009; Richmond and Freedman 2009; De Waal 2009), which would be used by the Conservative Party to make its case for qualifications reform (Sykes 2009). The Conservative Right now raised the question of what should be learned in the 14-19 phase, stepping into a curriculum vacuum left by New Labour, and provided the thinking behind what became Coalition Government policy on upper secondary education. It is for this reason that we refer below to the 'Conservative model' of general education.

\section{The Conservative model of general education - the new traditionalism}

The philosophical thinking behind current Conservative education policy was articulated in Michael Gove's lecture to the RSA in the year before the General Election. In this, he hailed the concept of a 'democratic intellect' in which it was every citizen's right to 'draw on our stock of intellectual capital' as part of education's 'emancipatory, liberating value'. He argued for a 'common stock of knowledge... which allows people to stand out against tides of opinion which are driven by passing fashions and populist rages' (Gove 2009). At the same time, he expressed concern about schools having wider social aims, which could divert them from the core task of passing on this stock of knowledge. He criticised 'progressive' approaches to education that had fragmented the study of history, robbed science of its serious content and that had elevated skills over the acquisition of knowledge. The consequences of this development were not only our slide down international PISA tables, but the production of an 'education apartheid', in which children from poor backgrounds were denied the knowledge that selective and independent schools embraced through the International GCSE and the International Baccalaureate. In terms of policy, Gove pronounced that his priority would be the restoring of discipline in the classroom, a higher profile given to selective qualifications, the reform of league tables to stretch the brightest, improving the quality of teachers being recruited to the profession and encouraging greater school autonomy. He concluded by lauding a 'traditional approach' to education, in which the common sense of the people would not be flouted by the educational establishment and bureaucracy. 
The roots of this Conservative view of education could be traced back decades, if not centuries. The language of emancipation and democracy might be new, but the focus on traditional general education subjects and knowledge transmission has, as we have seen, a long history. However, it was New Labour and its approach to general education that provided the focus for the Conservative re-articulation of traditionalism in its critique of bureaucracy and mechanicism. In the two years prior to the general election, right-wing think tanks and Conservative commissions produced a number of reports that laid out an alternative vision. Just prior to the General Election in May 2010, Reform published a report, A new level (Bassett et al. 2009), which heavily criticised the modular A levels that had resulted from the Curriculum 2000 reforms. The authors argued that a mechanically marked, modular A level had damaged the intellectual integrity of A level study, had hollowed out traditional subjects and was producing a generation of high maintenance students unable to think for themselves. They opposed wider participation in A levels, government control of qualifications, the system of equivalences in the National Qualifications Framework and even the International Baccalaureate that, they maintained, did not prepare young people for university. Instead, they recommended subject specialisation, the restoration of university control of $A$ levels, the re-establishment of linear syllabuses, increased granulation of results to aid selection at the top and the abolition of more applied qualifications, such as the Diploma.

In the same year, Policy Exchange published its influential report, Rising marks, falling standards (Richmond and Freeman 2009), which argued for three distinct routes 14-16 (academic, applied and vocational) based on more rigorous GCSEs, reformed Diplomas and Young Apprenticeships. Subjects would be reviewed in order to sit neatly within each route. In addition to these two reports, there have been two further interventions from the thinktank Civitas. The first, Straight As (De Waal 2009), trod much the same ground as Reform's A New level, but used evidence from a survey of A level teachers to recommend a greater 'market' in syllabuses, the scrapping of A level re-sits and delaying AS levels until the end of the first year of study so as to reduce lost teaching time. A more recent report from Civitas, Liberal education and the national curriculum (Conway 2010), is a polemic in favour of what the author terms liberal education. Here Conway supports a core of subjects, which could be seen as the justification of those selected for the English Baccalaureate, and the notion of a two-tier liberal education - education as 'culture' for those in independent schools and a 'basic' liberal education for the rest.

The influential Sykes report (2009) on GCSEs and A levels came from a working group convened by the Conservative Party and included a number of eminent academics, notably Professor Alison Wolf, who was given the task of reviewing vocational education for 14- to 19-year-olds (DfE 20I0b; Wolf 20II). It concluded that A levels were not fulfilling their prime function of selecting the most able for university or testing understanding; questioned the future of AS level and recommended that awarding bodies should be free to develop linear A level syllabuses; universities should become more involved in the regulation of qualifications and that there should be a new measure for GCSE achievement beyond that of gaining grades $A^{*}-C$ in five subjects, including mathematics and English.

The Conservative model of general education is still emerging, although its contours are becoming increasingly clear, as are its potential effects. Many of the ideas from the Sykes Report fed directly into the first Education White Paper, The importance of teaching: The schools White Paper 2010 (DfE 2010a), which proposed inter alia a review of the National Curriculum 'so that it becomes a benchmark outlining the knowledge and concepts pupils should be expected to master to take their place as educated members of society' (4I); the introduction of the English Baccalaureate and its use as a retrospective measure of school performance; the removal of modularity from GCSEs; the reduction in modularity and re-sit 
opportunities in A levels and a greater role for universities in their design. In terms of espoused philosophy, the Conservative approach is to support general education up to the age of 16. The apparent democratic tone of Gove's speech to the RSA, however, was not reflected in the White Paper. Here, the emphasis was on discipline in the classroom and the transmission of a body of academic knowledge, an approach, which has been described as 'static' (Young and Muller 20l0) or 'nostalgic' (Ball 20l I). At the same time, the English Baccalaureate general education track is being accompanied by the development of a more separate vocational education. The Wolf Review of 14-19 Vocational Education has prioritised the development of Apprenticeships and recommended the abolition of equivalences between general and applied/vocational qualifications (Wolf 20II). The promotion of 'hard subjects' and 'hard' vocational education has been accompanied by reports of derogatory references to 'soft subjects' (Shepherd 20II) and 'worthless qualifications' (Garner 20I0). In particular, there is a concerted attack on applied qualifications that lie between academic and vocational poles; a process being reinforced by selector universities. The Russell Group (20II), for example, has issued warnings that students who choose applied subjects at $A$ Level risk being rejected on the grounds that these qualifications are not sufficiently rigorous. Interacting with these curriculum and qualifications reforms is a radical organisational strategy - new academies, focusing on high performing schools, 'free schools' (DfE 20I0c) and new University Technical Colleges (BBC News 20I0). The White Paper suggests that academies will enjoy freedoms that will not extend to non-academy schools, which will be under pressure from Ofsted to meet the more challenging performance measures proposed in the White Paper.

The strengths of the Conservative model lie in its focus on the acquisition of knowledge, its apparent democratic intent and the potential it has to open up a debate about the aims and purposes of general education in the upper secondary. In this sense the Conservatives are asking an important question which New Labour did not. The model, however, harbours a number of potential dangers due to the way that curriculum and institutional policies interact and how policy levers drive institutional behaviour. Gove is introducing a hierarchy of institutions at the same time as a clearer hierarchy within general education and between general and vocational education. In a more market-driven system, we could see a new tripartite upper secondary arrangements emerging based on independent schools, grammar schools and academies at the top offering the English Baccalaureate and A levels; University Technical Colleges (UTCs) in the middle offering more apprenticeship-style experiences and maintained comprehensives at the bottom offering a mix of general and applied qualifications. Institutional tripartism would thus be underpinned by more rigid qualifications tracks from 14, hence realising the system advocated by the rightwing think tanks.

At the institutional level, we are already witnessing the effects of the English Baccalaureate performance measure as a leading policy lever. In our local studies, schools, and particularly those who feel under pressure from Ofsted, are changing their curriculum at Key Stage 4 to ensure that a greater proportion of the cohort have access to GCSE English Baccalaureate subjects. This could divert resources away from applied subjects into areas such as modern languages and history at a time of resource constraint. Moreover, there are already signs that subjects outside the English Baccalaureate, such as Art and Design, are being excluded from the Key Stage 4 curriculum as some schools scramble to meet the new benchmark (Mansell 20II). Changes to the curriculum could have a particularly negative effect on those middle and lower attainers, who initially benefited from the New Labour reforms, as the attention of schools switches from them to the more able, who will be the focus of the English Baccalaureate. 
A third negative effect is the tying of general education to a more restrictive and traditional view of knowledge and to GCSEs and A levels, which privilege a certain type of learning and assessment that is likely to be reinforced by the revised National Curriculum. The English Baccalaureate is based on the acquisition of five prescribed good GCSE grades that, in effect, implies that general upper secondary education is for some learners and not for all. The selection of subjects for the English Baccalaureate also declares that the arts, social sciences and the applied and vocational worlds are of lesser importance. In this sense, it does not adequately speak to modern society. Moreover, the Conservative approach to the National Curriculum - the memorising of facts and the transmission of a canon of knowledge - fails to problematise the relationship between knowledge acquisition and criticality. Thus the motives behind the Gove curriculum revolution may be less about 'deep thinking' and more about knowledge control.

Finally, the general education model cannot be seen in isolation from the conduct of the policy process. Despite rhetoric about respect for professionalism, institutional autonomy and a new approach to localism and devolution (Department for Business, Innovation and skills [BIS] 20I0), Coalition education policy is being conducted at high speed, in which institutions find themselves taking short-term curriculum decisions without fully thinking through their implications for learner achievement and progression.

\section{Conclusion: towards a more expansive and comprehensive model of general edu- cation?}

It could be argued that the Conservatives have been asking the right questions, but offering the wrong approach, while New Labour tried to offer the right approach, but did not ask the right questions. Thus, there is a case for a third model of general education, able to ask the right questions and to offer the right approach.

We have suggested that New Labour's model attempted to open up access and to promote attainment in general education by encouraging the mixing of general and applied qualifications. It had progressive aims - motivating young people to achieve and to aim higher, particularly middle attainers and suggesting that young people should engage with the world of application and production. However, New Labour became too focused on performativity and relied too much on policy levers. Tying mixing of study to league table improvement produced diverse reactions - the most high performing schools ignored it; others wholly embraced it but, in doing so, sometimes skewed their timetables to deny many young people the opportunity to study a range of general education subjects; and some focused the mixing on a particular part of the cohort where the most rapid improvement of results would be forthcoming. In this sense, it was not comprehensive. Moreover, it was expansive only in the most superficial sense. New Labour failed to pose curriculum questions about other aspects of general education, having invested heavily in the new Diplomas.

The Conservative model, with its emphasis on knowledge, could be seen as both critique and as corrective action. Its central argument is that young people should engage with fundamental disciplines in upper secondary education and to do so is empowering. It is here that we can see the echoes of the Scottish concept of the 'democratic intellect' (Davie 196I), which Gove used in his RSA speech. This term is more commonly associated with the role of universities sharing academic disciplines, such as philosophy, more widely with the public through their civic role (Paterson 2003). However, the English Baccalaureate proposal in practice is a pale reflection of this ambition. It is a performance measure that prescribes five subjects only and is not a curriculum in the wider sense; it ties their attainment solely to 
level 2 which, under present conditions, excludes the majority of young people and is also underpinned by a narrow notion of a transmittable body of knowledge rather than balancing knowledge, skill and criticality. Notwithstanding its legitimate educational challenge, the Conservative model of general education is as restrictive as New Labour's, if not more so. Nevertheless, despite their limitations, the New Labour and Conservative models pose a number of challenges for any alternative approach.

How can we develop an expansive model of general education that embraces different types of knowledge and skill and relates them in a coherent and manageable way? A first step would be to become more explicit about the types of knowledge and thinking to be developed (e.g., commonsense, theoretical and practical - Pring 1995); about the range of experiences that all young people should have (e.g., within and beyond schooling) and about the kind of attributes that the education system was seeking to develop (e.g., curiosity, persistence, taking risks, compassion, taking pride in doing a good job, confronting difficulties and the threat of failure).

Explicitness is but a start. Given the amount of knowledge competing to enter the curriculum, how could an expansive approach be concretely developed? It would be important, for example, to balance the centrality of certain areas of knowledge (the challenge of the English Baccalaureate subjects) with the recognition of other types of knowledge that have entered the curriculum more recently or represent other areas of human endeavour. As such, a balanced curriculum approach could be organised in domains that represent different forms of thinking and areas of knowledge (e.g., mathematical and scientific, the humanities, languages, the arts and the applied/vocational) and within these, learners could choose different subjects at different times, thus attempting to reconcile choice with the challenge of knowing what is deemed essential. Some baccalaureate designs do indeed take this approach (Phillips and Pound 2003).

How can knowledge, skill and criticality be developed together? It is important to recognise that all learners have to possess a basis of knowledge that is more than the commonsense accumulated beyond schooling. At the same time, it is equally important to understand the relationship between knowledge and skill (Young and Muller 2010) and to promote the fostering of criticality that adopts a questioning of knowledge itself. In terms of curriculum and pedagogy, these three related capacities will have to be pursued within disciplines and across the curriculum as a whole, with opportunities to explore subjects and topics in depth, through the introduction, for example, of a research or extended project at various points within the 14-19 phase. Given the influence of assessment on learning, its development will require much greater professional discretion in terms of both the teaching and assessment of subjects and the use of peer moderation, with external examinations playing a checking and balancing role.

But can an expansive model of general education be comprehensive - can it apply to all learners? Here we argue that it can, if it is not restricted to a particular level of attainment or to particular forms of knowledge and activity. Comprehensiveness thus refers both to the range of learners and levels included in general education as well as its relationship with vocational education. If we take Gove's argument about the democratic intellect to its logical conclusion, general education beyond the age of 14 has to be for all and not just for some. It cannot, therefore, be tied to the achievement of a particular examination at 16 and principally guided by selection. Rather, an expansive form of general education should be accessible to all and recognised at all levels - the music test approach. It should also be available throughout the 14-19 phase and form a part of vocational learning, as is the case in other European systems (Clarke and Winch 2007). The question is not whether general education should be present in vocational education, but what form it should take. 
Both the New Labour and Conservative models of general education have relied on topdown policy levers to steer institutional behaviour. In their different ways, they are both bureaucratic. Is it possible for a third model of general education to be conducted in a different way? Recent research on governance suggests that a more democratic and lateral approach is possible; with an emphasis on the creation of collaborative local learning systems to meet the needs of all learners in a locality (Hodgson and Spours 2006); the development of 'policy frameworks', rather than policy levers, designed to invite wider participation in policy enactment and to promote equity (Coffield et al. 2008) and more democratic forms of accountability (Ranson 2006). Underpinning these developments would be a much slower, deliberative and inclusive policy process (Raffe and Spours 2007), with the intention of creating a stable and evolving environment in which professionals and others social partners would be able to debate and discuss difficult and challenging issues and to bring about slow but durable change.

\section{Notes on contributors}

Ann Hodgson and Ken Spours are both Professors of Education and Co-Directors of the Centre for Post-14 Research and Innovation at the Institute of Education, University of London. Ann is currently Faculty Director for Research, Consultancy and Knowledge Transfer and Ken is Head of the Department of Continuing and Professional Education.

\section{References}

Ball, S. 20I I. Back to the nineteenth century with Michael Gove's Education Bill. The Guardian, 3I January. http://www.guardian.co.uk/commentisfree/20I I/jan/3I/michael-gove-education-bill.

Bassett, D., T. Cawston, L. Thraves, and E. Truss. 2009. A new level. London: Reform.

BBC News. 2007. Diplomas 'could replace A-levels'. 23 October. http://news.bbc.co.uk/I/hi/education/ $7058015 . s t m$.

BBC News. 2010. Target for 40 university technical colleges. 17 November. http://www.bbc.co.uk/ news/education-I I 776453.

Blackstone, T. 1998. Qualifying for success: The response to the Qualifications and Curriculum Authority advice, 3 April. London: Department for Education and Skills.

Clarke, L., and C. Winch. 2007. Vocational education: International approaches and systems. London: Routledge.

Coffield, F., S. Edward, I. Finlay, A. Hodgson, K. Spours, and R. Steer. 2008. Improving learning, skills and inclusion: The impact of policy on post-compulsory education. London: Routledge.

Conway, D. 20I0. Liberal education and the national curriculum. London: Civitas.

Crowther, G. 1959. 15-18. Report of the Central Advisory Council for Education (England). London: HMSO.

Dale, R. 1985. Education, training and employment. Milton Keynes: Open University Press.

Davie, G. 196I. The democratic intellect: Scotland and her universities in the nineteenth century. Edinburgh: Edinburgh University Press.

Department for Business, Innovation and Skills (BIS). 20I0. Local growth: Realising every place's potential. $\mathrm{Cm}$ 796I. London: BIS.

Department of Education and Science (DES). 1976. School education in England: Problems and initiatives. London: DES.

Department for Education (DfE). 2010a. The importance of teaching: The schools White Paper 2010. London: DfE.

DfE. 20lOb. Education Secretary Michael Gove announces review of 14-19 vocational education. 9 September. http://www.education.gov.uk/inthenews/pressnotices/a0064346/education-secretarymichael-gove-announces-review-of-14-to-19-vocational-education.

DfE. 2010c. Michael Gove invites all schools to become academies. 26 May. http://www.education.gov.uk/ news/news/academies.

DfE, and BIS. 2010a. Participation in education, training and employment by 16-18 year olds in England. http://www.education.gov.uk/rsgateway/index.shtml.

DfE, and BIS. 20I0b. GCSE and equivalent results in England 2009/10 (provisional). http://www.education. gov.uk/rsgateway/DB/SFR/s000963/index.shtml. 
DfE, and BIS. 20II. GCE/applied GCE A/AS and equivalent results in England 2009//0 (revised). http://www. education.gov.uk/rsgateway/DB/SFR/s000986/index.shtml.

Department for Education and Skills (DfES). 2003. 14-19 Excellence and opportunity: Government response to the 14-19 Green Paper. London: DfES.

DfES. 2005. 14-19 education and skills. London: DfES.

DfES. 2005. 14-19 implementation plan. London: DfES.

De Waal, A. 2009. Straight 'A's? A level teachers' views on today's A levels. London: Civitas.

Fisher, L. 2007. Pedagogy and the Curriculum 2000 reforms at post-16: The 'learn it, forget it' culture. The Curriculum Journal 18, no. I: 103-4.

Garner, R. 2010. Harrow head attacks 'worthless qualifications'. The Independent, 22 January. http:// www.independent.co.uk/news/education/education-news/harrow-head-attacks-worthless-qualifications- I8762 I 9.html.

Gleeson, D. 1987. The technical and vocational education initiative and secondary education. Milton Keynes: Open University Press.

Golden, S., L. O'Donnell, and P. Rudd. 2005. Evaluation of increased flexibility for I4-I6 year olds programme: The second year. RR609. Nottingham: DfES.

Gordon, P. 2002. Curriculum. In A century of education, ed. R. Aldrich, 185-205. London: Routledge Falmer.

Gove, M. 2009. What is education for? Speech by Michael Gove MP to the RSA, 30 June.

Gove, M. 2010. Speech to Teach First annual awards at Westminster Academy, 6 September. http:// www.education.gov.uk/news/speeches/mgwestminsteracademy.

Green, A. 1990. Education and state formation: The rise of education systems in England, France and the USA. London: Macmillan.

Hodgson, A., and K. Spours. 1997. Dearing and beyond: 14-19 qualifications, frameworks and systems. London: Kogan Page.

Hodgson, A., and K. Spours. 2006. The organization of 14-19 education and training in England: Beyond weakly collaborative arrangements. Journal of Education and Work 19, no. 4: 325-42.

Hodgson, A., and K. Spours. 2008. Education and training 14-19: Curriculum, qualifications and organisation. London: Sage.

Hodgson, A., and K. Spours. 2009. Collaborative local learning ecologies: Reflections on the governance of lifelong learning in England. Inquiry into the future for lifelong learning sector paper 6. Leicester: NIACE.

Hopkins, A. 1978. The school debate. Harmondsworth: Penguin Books.

Kingswood Area Progression Project. 2010a. Year 10 learners talk about their experience of the first year of Key Stage 4. KAPP discussion paper 10. http://www.ioe.ac.uk/research/3273I.html.

Kingswood Area Progression Project. 2010b. Key messages from the first two years of the Kingswood Area Progression Project. KAPP discussion paper I I. http://www.ioe.ac.uk/research/3273I.html.

Kingswood Area Progression Project. 2010c. 14-19 attainment and progression: Perspectives from post-16 professionals. KAPP discussion paper 12. http://www.ioe.ac.uk/research/3273I.html.

Mansell, W. 20II. The English BAC causes fury in schools. The Guardian, II January. http://www.guardian.co.uk/education/20I I/jan/ I I/league-table-secondary-english-baccalaureate.

McCulloch, G. 2002. Secondary education. In A century of education, ed. R. Aldrich, 3I-53. London: Routledge Falmer.

Newman, J. 2000. Beyond the new public management? Modernizing public services. In New managerialism, new welfare?, eds. J. Clarke, S. Gewirtz, and E. McLoughlin, 46-60. London: Sage.

Newsom, J. 1963. Half our future. A report of the Central Advisory Council for Education. London: HMSO.

North East Lincolnshire Partnership Progression Project. 2010. Reviewing transition and progression at 14+: A partnership approach. Discussion paper I. http://www.ioe.ac.uk/research/49007.html.

Oates, T. 2010. Could do better: Using international comparisons to refine the national curriculum in England. Cambridge: Cambridge Assessment.

Paterson, L. 2003. The survival of the democratic intellect: Academic values in Scotland and England. Higher Education Quarterly 57, no. I: 67-93.

Phillips, G., and T. Pound. 2003. The Baccalaureate: A model for curriculum reform. London: Kogan Page.

Pring, R. 1995. Closing the gap: Liberal education and vocational preparation. London: Hodder and Stoughton.

Pring, R., G. Hayward, A. Hodgson, J. Johnson, E. Keep, A. Oancea, G. Rees, K. Spours, and S. Wilde. 2009. Education for all: The future of education and training for 14-19 year olds. London: Routledge.

Raffe, D., and K. Spours. 2007. Policy-making and policy learning in 14-19 education. London: Institute of Education, University of London Bedford Way Papers. 
Ranson, S. 2006. Public accountability in the age of neo-liberal governance. In Education policy and politics, eds. B. Lingard and J. Ozga, 459-80. London: Routledge/Falmer.

Richardson, W. 2009. Young undergraduate entrants to UK higher education: The strengthening relationship between leading universities and independent schools. Exeter: University of Exeter Graduate School of Education.

Richmond, T., and S. Freedman. 2009. Rising marks, falling standards. London: Policy Exchange.

Russell Group. 20II. New guidance on post-16 study choices. February 4. http://www.russellgroup.ac. uk/russell-group-latest-news/I37-20I I/4746-new-guidance-on-post I6-study-choices/.

Shepherd, J. 20II. Gove blames Labour for 'soft' subjects studied. The Guardian, February 4. http:// www.guardian.co.uk/education/20I I/feb/04/gove-soft-subjects.

Sykes, R. 2009. The Sir Richard Sykes review of GCSEs and A levels. London: Conservative Party.

Wolf, A. 20II. Review of vocational education: The Wolf report. London: DfE.

Working Group on 14-19 Reform. 2004. 14-19 curriculum and qualifications reform: Final report. London: DFES.

Young, M., and J. Muller. 2010. Three educational scenarios for the future: Lessons from the sociology of knowledge. European Journal of Education 45, no. I: II-27. 